RCN International Nursing Research Conference and

Exhibition 2015

Monday 20 - Wednesday 22 April 2015

East Midlands Conference Centre, Nottingham

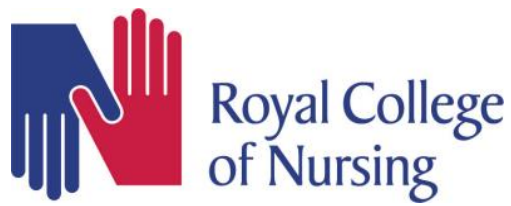

\title{
Programme at a glance
}

Monday 20 April 2015

$08.00-10.00 \quad$ Registration, refreshments, exhibition and poster judging/ viewing

$10.00-10.10 \quad$ Chairs' welcome and introduction to the conference

$10.10-10.20 \quad$ Welcome to Nottingham

Professor Patrick Callaghan, School of Health Sciences, University of Nottingham

$10.20-11.00 \quad$ Invisible care in 'soulless factories'?

The challenges of humanising healthcare for patients and nurses

Professor Jill Maben, Chair in Nursing Research,

Kings College London

$11.00-11.30 \quad$ Refreshments, exhibition viewing, poster judging/viewing

\section{$11.30-12.55 \quad$ Concurrent session 1}

\begin{tabular}{|c|c|c|c|c|c|}
\hline \multicolumn{6}{|c|}{ Concurrent session 1} \\
\hline & $11.30-11.55$ & \multirow[b]{2}{*}{ 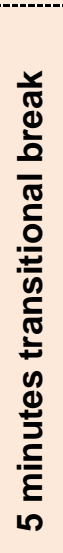 } & $12.00-12.25$ & \multirow[b]{2}{*}{ 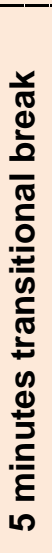 } & $12.30-12.55$ \\
\hline 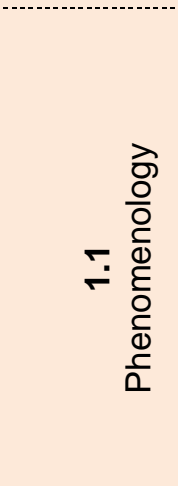 & $\begin{array}{l}\text { Abstract number } 23 \\
\text { Pieces of the jigsaw: } \\
\text { what support do multi- } \\
\text { skilled emergency nurses } \\
\text { need to deliver alcohol } \\
\text { brief intervention } \\
\text { education in a small rural } \\
\text { Emergency Department? } \\
\text { Elizabeth Ann McCall, } \\
\text { Byron District Hospital, } \\
\text { Australia }\end{array}$ & & $\begin{array}{l}1.1 .2 \\
\text { Abstract number } 25 \\
\text { Registered nurses' } \\
\text { experiences of respect } \\
\text { towards service users: } \\
\text { an interpretative } \\
\text { phenomenological } \\
\text { analysis } \\
\text { Hazel Margaret Chapman, } \\
\text { University of Chester, } \\
\text { United Kingdom }\end{array}$ & & $\begin{array}{l}\text { Abstract number } 265 \\
\text { Experiences of } \\
\text { disengagement from } \\
\text { mental health services: } \\
\text { An interpretative study } \\
\text { Chris Wagstaff, College of } \\
\text { Medical \& Dental Sciences, } \\
\text { United Kingdom }\end{array}$ \\
\hline
\end{tabular}




\begin{tabular}{|c|c|c|c|}
\hline 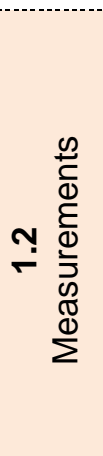 & $\begin{array}{l}1.2 .1 \\
\text { Abstract number } 234 \\
\text { Clinical signs of water- } \\
\text { loss dehydration are } \\
\text { ineffective in older people } \\
\text { living in residential care } \\
\text { Diane Bunn, University of } \\
\text { East Anglia, United } \\
\text { Kingdom }\end{array}$ & $\begin{array}{l}1.2 .2 \\
\text { Abstract number } 277 \\
\text { Measuring the quality of } \\
\text { end-of-life care amongst } \\
\text { hospice patients, close } \\
\text { persons and healthcare } \\
\text { professionals } \\
\text { Dr Cara Bailey, University } \\
\text { of Birmingham, United } \\
\text { Kingdom }\end{array}$ & $\begin{array}{l}1.2 .3 \\
\text { Abstract number } 147 \\
\text { Reducing malnutrition in } \\
\text { nursing homes using } \\
\text { foods with an } \\
\text { appropriate texture for } \\
\text { dysphagic older people: } \\
\text { First results of the } \\
\text { NUTRICARE project } \\
\text { Dr. Milko Zanini, University } \\
\text { of Genoa, Italy }\end{array}$ \\
\hline 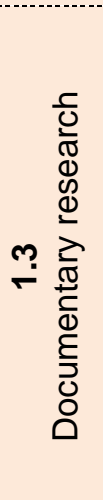 & $\begin{array}{l}1.3 .1 \\
\text { Abstract number } 26 \\
\text { Nursing history: new } \\
\text { approaches to } \\
\text { dissemination } \\
\text { Dr Jill Clendon, New } \\
\text { Zealand Nurses } \\
\text { Organisation, New Zealand }\end{array}$ & $\begin{array}{l}1.3 .2 \\
\text { Abstract number } 152 \\
\text { Through the looking } \\
\text { glass: Transforming } \\
\text { children's nursing } \\
\text { research culture within a } \\
\text { healthcare organisation } \\
\text { through an innovative } \\
\text { leadership approach } \\
\text { Joseph Manning, The } \\
\text { University of Nottingham, } \\
\text { United Kingdom }\end{array}$ & $\begin{array}{l}1.3 .3 \\
\text { Abstract number } 35 \\
\text { The art of maintaining } \\
\text { creativity in a risk averse } \\
\text { culture. } \\
\text { Professor Austyn } \\
\text { Snowden, University of the } \\
\text { West of Scotland, United } \\
\text { Kingdom }\end{array}$ \\
\hline 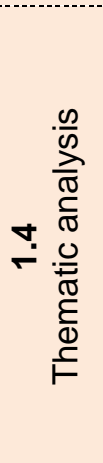 & $\begin{array}{l}1.4 .1 \\
\text { Abstract number } 250 \\
\text { Brainstem Death: A } \\
\text { Family Affair } \\
\text { Majella Doran, HSC Clinical } \\
\text { Education Centre, United } \\
\text { Kingdom }\end{array}$ & $\begin{array}{l}1.4 .2 \\
\text { Abstract number } 105 \\
\text { Balancing hope and } \\
\text { despair at the end of life: } \\
\text { The contribution of } \\
\text { organ and tissue } \\
\text { donation } \\
\text { Dr Wendy Walker, } \\
\text { University of } \\
\text { Wolverhampton, United } \\
\text { Kingdom }\end{array}$ & $\begin{array}{l}1.4 .3 \\
\text { Abstract number } 173 \\
\text { Patients' worries about } \\
\text { money, work and } \\
\text { relationships during } \\
\text { recovery from a serious } \\
\text { physical illness or injury } \\
\text { Dr Sarah Earthy, University } \\
\text { of Surrey, United Kingdom }\end{array}$ \\
\hline 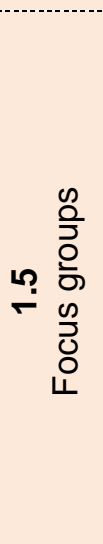 & $\begin{array}{l}1.5 .1 \\
\text { Abstract number } 191 \\
\text { Development and } \\
\text { feasibility of a mouth } \\
\text { hygiene education and } \\
\text { training programme in } \\
\text { stroke unit care } \\
\text { Dr Maria Horne, University } \\
\text { of Bradford, United } \\
\text { Kingdom }\end{array}$ & $\begin{array}{l}1.5 .2 \\
\text { Abstract number } 162 \\
\text { An exploratory study to } \\
\text { investigate the role of } \\
\text { 'Volunteer Dementia } \\
\text { Champions' in providing } \\
\text { encouragements with } \\
\text { eating and drinking as } \\
\text { well a companionship for } \\
\text { patients with dementia in } \\
\text { acute hospital wards: } \\
\text { Dr Ruth Davies, Swansea } \\
\text { University, United Kingdom }\end{array}$ & $\begin{array}{l}1.5 .3 \\
\text { Abstract number } 141 \\
\text { Silent voices: exploring } \\
\text { women's experience of } \\
\text { health care professionals } \\
\text { responses to domestic } \\
\text { violence and abuse } \\
\text { Dr Julie McGarry, } \\
\text { University of Nottingham, } \\
\text { United Kingdom }\end{array}$ \\
\hline 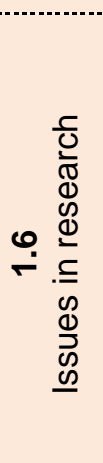 & $\begin{array}{l}\text { 1.6.1 } \\
\text { Abstract number } 194 \\
\text { Seeds For The Future: } \\
\text { Developing Arts-Based, } \\
\text { Creative Approaches for } \\
\text { Researchers engaging } \\
\text { with Children } \\
\text { Professor Jane Coad, } \\
\text { Coventry University, United } \\
\text { Kingdom }\end{array}$ & $\begin{array}{l}1.6 .2 \\
\text { Abstract number } 264 \\
\text { Originality in doctoral } \\
\text { research: what is it and } \\
\text { how can it be } \\
\text { demonstrated? } \\
\text { Dr Paul Gill, Cardiff } \\
\text { University, United Kingdom }\end{array}$ & $\begin{array}{l}1.6 .3 \\
\text { Abstract number } 85 \\
\text { The State of European } \\
\text { Nursing Research: Dead, } \\
\text { Alive, or Chronically } \\
\text { Diseased? A Systematic } \\
\text { Literature Review } \\
\text { Professor David Richards, } \\
\text { University of Exeter } \\
\text { Medical School, United } \\
\text { Kingdom }\end{array}$ \\
\hline
\end{tabular}




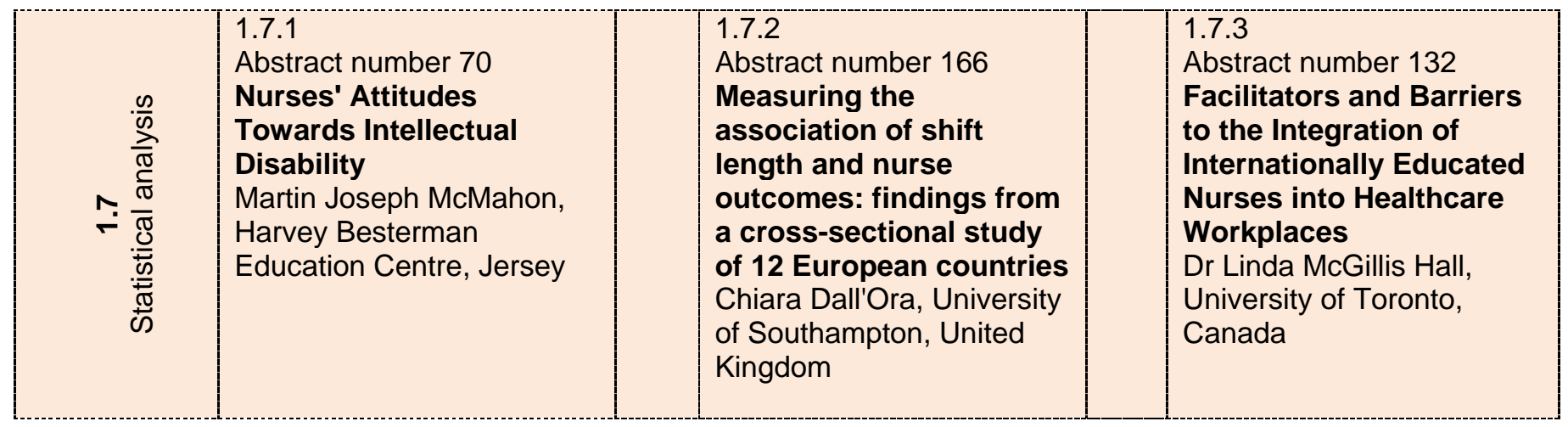

\subsection{5 - $13.55 \quad$ Lunch, exhibition viewing, poster judging/viewing}

Presenters will be at their posters from 13.25 - 13.55

\subsection{5 - $15.40 \quad$ Concurrent session 2}

\begin{tabular}{|c|c|c|c|c|c|}
\hline \multicolumn{6}{|c|}{ Concurrent session 2} \\
\hline & $13.55-14.20$ & \multirow{3}{*}{ 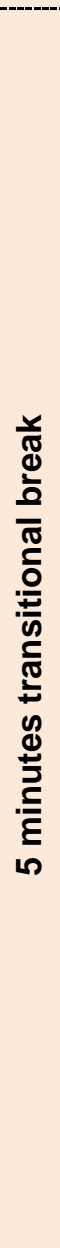 } & $14.25-14.50$ & \multirow{3}{*}{ 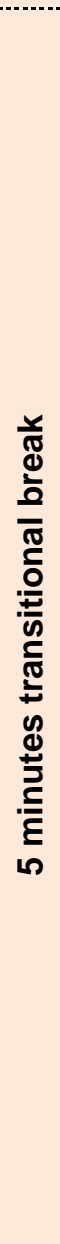 } & $14.55-15.20$ \\
\hline 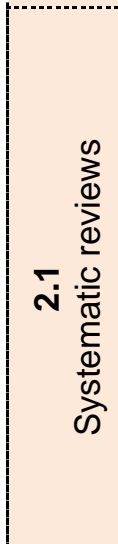 & $\begin{array}{l}2.1 .1 \\
\text { Abstract number } 290 \\
\text { What factors influence } \\
\text { the attitudes of Health } \\
\text { Care providers in the } \\
\text { pain management of } \\
\text { Sickle Cell Disease? } \\
\text { Sittana Abdelmagid, City } \\
\text { University, London, } \\
\text { United Kingdom }\end{array}$ & & $\begin{array}{l}2.1 .2 \\
\text { Abstract number } 38 \\
\text { Health Dialogue: a } \\
\text { concept analysis } \\
\text { Dr Marianne Reid, } \\
\text { University of the Free } \\
\text { State, South Africa }\end{array}$ & & $\begin{array}{l}2.1 .3 \\
\text { Abstract number } 284 \\
\text { Variables associated with } \\
\text { alcohol relapse and } \\
\text { psychosocial interventions } \\
\text { to prevent alcohol relapse in } \\
\text { liver transplant patients for } \\
\text { alcoholic liver disease: a } \\
\text { systematic review } \\
\text { lyoni Ranasinghe, South } \\
\text { London and Maudsley NHS } \\
\text { Foundation Trust, United } \\
\text { Kingdom }\end{array}$ \\
\hline 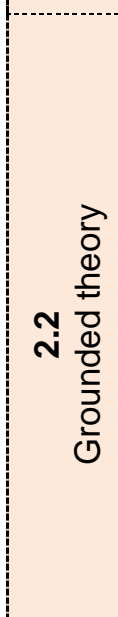 & $\begin{array}{l}2.2 .1 \\
\text { Abstract number } 202 \\
\text { The experiences of ST- } \\
\text { elevation myocardial } \\
\text { infarction (STEMI) } \\
\text { patients who are } \\
\text { readmitted within } 6 \\
\text { months of primary } \\
\text { percutaneous coronary } \\
\text { intervention (PPCI) } \\
\text { treatment } \\
\text { Dr Heather lles-Smith, } \\
\text { Leeds Teaching Hospitals } \\
\text { NHS Trust, United } \\
\text { Kingdom }\end{array}$ & & $\begin{array}{l}2.2 .2 \\
\text { Abstract number } 200 \\
\text { A humanistic trajectory of } \\
\text { critical illness - patient } \\
\text { perspectives } \\
\text { Pamela Page, Anglia } \\
\text { Ruskin University, United } \\
\text { Kingdom }\end{array}$ & & $\begin{array}{l}2.2 .3 \\
\text { Abstract number } 177 \\
\text { Psychosocial impact of } \\
\text { newborn screening for sickle } \\
\text { cell disease: parental } \\
\text { perspectives. } \\
\text { Dr Jane Chudleigh, King's } \\
\text { College London, United } \\
\text { Kingdom }\end{array}$ \\
\hline
\end{tabular}




\begin{tabular}{|c|c|c|c|}
\hline 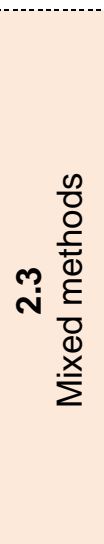 & $\begin{array}{l}2.3 .1 \\
\text { Abstract number } 215 \\
\text { The Cassandra Project- } \\
\text { Building A Sustainable } \\
\text { Workload Activity Model } \\
\text { for Future Community } \\
\text { and District Nursing } \\
\text { Workforce Capacity } \\
\text { Planning } \\
\text { Carolyn Jackson, } \\
\text { Canterbury Christ Church } \\
\text { University, United } \\
\text { Kingdom }\end{array}$ & $\begin{array}{l}2.3 .2 \\
\text { Abstract number } 192 \\
\text { Support matters: a mixed } \\
\text { methods scoping study } \\
\text { on the use of assistant } \\
\text { staff in the delivery of } \\
\text { community nursing } \\
\text { services in England } \\
\text { Professor Karen Spilsbury, } \\
\text { University of York, United } \\
\text { Kingdom }\end{array}$ & $\begin{array}{l}2.3 .3 \\
\text { Abstract number } 164 \\
\text { Living Well With Dementia: } \\
\text { Enhancing Dignity And } \\
\text { Quality Of Life, Using A } \\
\text { Novel Intervention, Dignity } \\
\text { Therapy } \\
\text { Professor Bridget Johnston, } \\
\text { The University of Nottingham, } \\
\text { United Kingdom }\end{array}$ \\
\hline 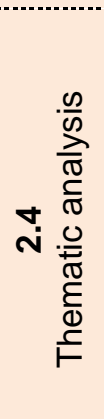 & $\begin{array}{l}2.4 .1 \\
\text { Abstract number } 48 \\
\text { Sources of stress in } \\
\text { healthy Chinese } \\
\text { siblings of children with } \\
\text { cancer: preliminary } \\
\text { results of a prospective } \\
\text { longitudinal study } \\
\text { Ru-Hwa Wang, Cardinal } \\
\text { Tien Hospital, Taiwan }\end{array}$ & $\begin{array}{l}2.4 .2 \\
\text { Abstract number } 66 \\
\text { The tight rope of caring } \\
\text { for refugees: } \\
\text { perspectives of refugee } \\
\text { health nurses. } \\
\text { Professor Lesley Wilkes, } \\
\text { Nepean Blue Mountains } \\
\text { Local Health District, } \\
\text { Australia }\end{array}$ & $\begin{array}{l}2.4 .3 \\
\text { Abstract number } 220 \\
\text { Foreign paediatric patients } \\
\text { with a stem cell transplant: } \\
\text { what is the nurses' } \\
\text { perception? } \\
\text { Annamaria Bagnasco, } \\
\text { University of Genoa, Italy }\end{array}$ \\
\hline 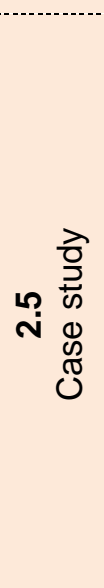 & $\begin{array}{l}2.5 .1 \\
\text { Abstract number } 245 \\
\text { Talent Management in } \\
\text { Nursing } \\
\text { Sue Haines, Nottingham } \\
\text { University Hospitals NHS } \\
\text { Trust, United Kingdom }\end{array}$ & $\begin{array}{l}2.5 .2 \\
\text { Abstract number } 190 \\
\text { United Kingdom National } \\
\text { Health Service (NHS) } \\
\text { workforce } \\
\text { transformation: A case } \\
\text { study of the critically ill } \\
\text { patient's journey on a } \\
\text { care pathway in an } \\
\text { integrated care } \\
\text { organisation. } \\
\text { Abdelhakim Altabaibeh, } \\
\text { The Whittington Hospital, } \\
\text { United Kingdom }\end{array}$ & $\begin{array}{l}2.5 .3 \\
\text { Abstract number } 160 \\
\text { Understanding the End of } \\
\text { life clinical problems of } \\
\text { younger adults and its } \\
\text { impact on their parents, } \\
\text { siblings and health } \\
\text { professionals within the } \\
\text { context of life transitions to } \\
\text { enhance their wellbeing } \\
\text { Professor Bridget Johnston, } \\
\text { The University of Nottingham,, } \\
\text { United Kingdom }\end{array}$ \\
\hline 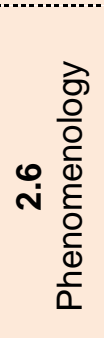 & $\begin{array}{l}2.6 .1 \\
\text { Abstract number } 236 \\
\text { Emotion work: The } \\
\text { invisible labour of } \\
\text { health visiting } \\
\text { Jillian Taylor, University of } \\
\text { the West of Scotland, } \\
\text { United Kingdom }\end{array}$ & $\begin{array}{l}2.6 .2 \\
\text { Abstract number } 47 \\
\text { Health visitors' views of } \\
\text { compassion } \\
\text { Margaret Clarke, University } \\
\text { of Leeds, United Kingdom }\end{array}$ & $\begin{array}{l}2.6 .3 \\
\text { Abstract number } 237 \\
\text { In Their Shoes: an } \\
\text { ontological perspective on } \\
\text { empathy in nursing practice } \\
\text { John McKinnon, University of } \\
\text { Lincoln, United Kingdom }\end{array}$ \\
\hline 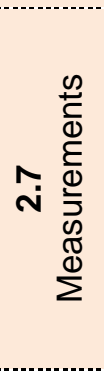 & $\begin{array}{l}2.7 .1 \\
\text { Abstract number } 334 \\
\text { Lactate - Arterial and } \\
\text { Venous Agreement in } \\
\text { Sepsis (LAVAS) } \\
\text { Julia Grahamslaw, Royal } \\
\text { Infirmary of Edinburgh, } \\
\text { United Kingdom }\end{array}$ & $\begin{array}{l}2.7 .2 \\
\text { Abstract number } 301 \\
\text { Mentor's behaviour in } \\
\text { clinical nursing } \\
\text { education- a scale } \\
\text { development and } \\
\text { validation } \\
\text { Yanhua Chen, University of } \\
\text { Hull, United Kingdom }\end{array}$ & $\begin{array}{l}2.7 .3 \\
\text { Abstract number } 336 \\
\text { Capillary and Venous } \\
\text { Lactate Agreement - a pilot } \\
\text { observational study } \\
\text { Julia Grahamslaw, Royal } \\
\text { Infirmary of Edinburgh, United } \\
\text { Kingdom }\end{array}$ \\
\hline
\end{tabular}

$15.20-15.50 \quad$ Refreshments, exhibition viewing, poster judging/viewing

$15.50-16.45 \quad$ Concurrent session 3 


\begin{tabular}{|c|c|c|c|}
\hline \multicolumn{4}{|c|}{ Concurrent session 3} \\
\hline & $15.50-16.15$ & \multirow{7}{*}{ 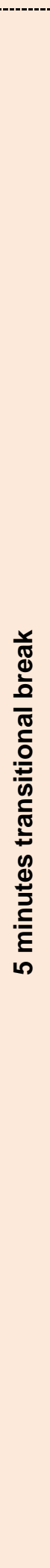 } & $16.20-16.45$ \\
\hline 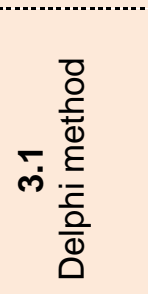 & $\begin{array}{l}3.1 .1 \\
\text { Abstract number } 34 \\
\text { Inclusive leadership and the nursing } \\
\text { profession } \\
\text { Dr Philip Esterhuizen, University of Leeds, } \\
\text { United Kingdom }\end{array}$ & & $\begin{array}{l}3.1 .2 \\
\text { Abstract number } 117 \\
\text { The role and competencies of Advanced } \\
\text { Nurse Practitioners working with frail older } \\
\text { people: A Delphi study. } \\
\text { Dr Sarah Goldberg, University of Nottingham, } \\
\text { United Kingdom }\end{array}$ \\
\hline Nָ & $\begin{array}{l}3.2 .1 \\
\text { Abstract number } 286 \\
\text { Congenital Heart Disease: A survey of } \\
\text { young adults' knowledge and } \\
\text { understanding of their heart condition } \\
\text { Elaine Muirhead, Golden Jubilee National } \\
\text { Hospital, United Kingdom }\end{array}$ & & $\begin{array}{l}3.2 .2 \\
\text { Abstract number } 41 \\
\text { Effect of Renal Rehabilitation on Quality of } \\
\text { Life Among Dialysis Patients } \\
\text { Dr Eilean Victoria Lazarus Rathinasamy, Sultan } \\
\text { Qaboos University, Oman }\end{array}$ \\
\hline 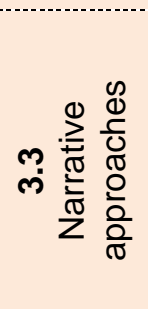 & $\begin{array}{l}3.3 .1 \\
\text { Abstract number } 37 \\
\text { The social consequences of living over } \\
\text { time with progressive breast cancer: a } \\
\text { narrative enquiry } \\
\text { Dr Elizabeth Reed, Princess Alice Hospice, } \\
\text { United Kingdom }\end{array}$ & & $\begin{array}{l}3.3 .2 \\
\text { Abstract number } 233 \\
\text { Exploring the impact of the environment for } \\
\text { those on an alcohol recovery journey through } \\
\text { Photovoice } \\
\text { Dr Sarah Rynas, The University of Edinburgh, } \\
\text { United Kingdom }\end{array}$ \\
\hline 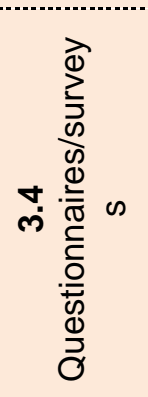 & $\begin{array}{l}3.4 .1 \\
\text { Abstract number } 100 \\
\text { Care closer to people's homes: profiling } \\
\text { the community nursing workforce. } \\
\text { Dr Julia Philippou, King's College London, } \\
\text { United Kingdom }\end{array}$ & & $\begin{array}{l}\text { A.4.2 } \\
\text { Abstract number } 3 \\
\text { A questionnaire survey of the experiences, } \\
\text { attitudes and opinions of Intensive Care } \\
\text { nurses in relation to the application of } \\
\text { physical restraint within two large Intensive } \\
\text { Care Units in the North of England } \\
\text { Samantha Freeman, The University of } \\
\text { Manchester, United Kingdom }\end{array}$ \\
\hline 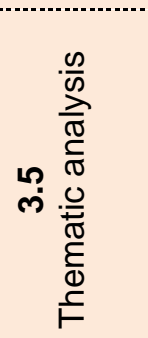 & $\begin{array}{l}3.5 .1 \\
\text { Abstract number } 257 \\
\text { Valuing Patient and Public Involvement } \\
\text { (PPI) in Patient-Reported Outcomes } \\
\text { (PRO) Research: an international PPI } \\
\text { Café. } \\
\text { Dr Kirstie Haywood, RCN Research } \\
\text { Institute, United Kingdom }\end{array}$ & & $\begin{array}{l}3.5 .2 \\
\text { Abstract number } 258 \\
\text { Satisfaction and perception with pain } \\
\text { management among Palliative Patients with } \\
\text { Breakthrough Pain } \\
\text { Dr Pathmawathi Subramanian, University of } \\
\text { Malaya, Malaysia }\end{array}$ \\
\hline 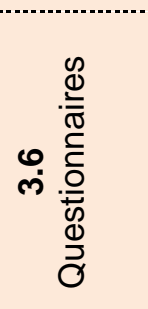 & $\begin{array}{l}3.6 .1 \\
\text { Abstract number } 76 \\
\text { Nurses' knowledge of pressure ulcers } \\
\text { and their management in Oman } \\
\text { Amal Al Shidi, University of Glasgow, United } \\
\text { Kingdom }\end{array}$ & & $\begin{array}{l}3.6 .2 \\
\text { Abstract number } 95 \\
\text { Do nurse led foot checks result in improved } \\
\text { reported foot self-care behaviour in } \\
\text { haemodialysis patients with diabetes? } \\
\text { Sarah Brand, Nottingham University Hospitals } \\
\text { Trust, United Kingdom }\end{array}$ \\
\hline 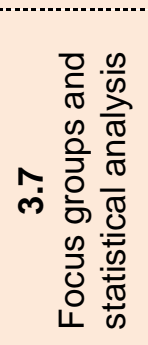 & $\begin{array}{l}3.7 .1 \\
\text { Abstract number } 311 \\
\text { Are we failing to prepare nursing and } \\
\text { midwifery students to deal with domestic } \\
\text { abuse? Findings from a qualitative study } \\
\text { Caroline Bradbury-Jones, University of } \\
\text { Birmingham, United Kingdom }\end{array}$ & & $\begin{array}{l}3.7 .2 \\
\text { Abstract number } 326 \\
\text { Time to Change?...An Exploration of Attitudes } \\
\text { Towards Mental Illness and Social Contact } \\
\text { Katie Pybus, Sheffield Health and Social Care } \\
\text { NHS Foundation Trust, United Kingdom }\end{array}$ \\
\hline
\end{tabular}


$16.50-17.50 \quad$ Fringe/ Networking events

\begin{tabular}{|l|l|l|}
$\begin{array}{l}\text { Maximizing the impact of } \\
\text { your publications in an } \\
\text { open access } \\
\text { environment } \\
\text { Professor lan Norman, } \\
\text { King's College London and } \\
\begin{array}{l}\text { Professor Peter Griffiths, } \\
\text { University of Southampton }\end{array}\end{array}$ & $\begin{array}{l}\text { Fellowship Opportunities } \\
\text { for Nurses from the } \\
\text { National Institute for } \\
\text { Health Research: what } \\
\text { are they and how do you } \\
\text { get one? } \\
\text { David Richards, } \\
\text { University of Exeter } \\
\text { Medical School }\end{array}$ & $\begin{array}{l}\text { Best evidence for best } \\
\text { practice: using social } \\
\text { media to share research } \\
\text { and engage nurses } \\
\text { Sarah Chapman and Holly } \\
\text { Millward, UK Cochrane } \\
\text { Centre }\end{array}$ \\
\hline
\end{tabular}

17.50

Close of day one

$18.00 \quad$ Welcome drinks reception at the EMCC 
$08.30-09.00 \quad \begin{aligned} & \text { Registration, refreshments, exhibition viewing \& poster } \\ & \text { judging/viewing }\end{aligned}$

$09.00-09.10 \quad$ Chairs' welcome and introduction to conference day two

$09.10-09.50 \quad$ Hoist on our own petard: the false dichotomy between technical and holistic care in nursing

Professor Siobhan Nelson, Vice-Provost, Academic Programs,

University of Toronto

$09.50-10.05 \quad$ Mary Seacole

$10.05-11.00 \quad$ Concurrent session 4

\begin{tabular}{|c|c|c|c|}
\hline \multicolumn{4}{|c|}{ Concurrent session 4} \\
\hline & $10.05-10.30$ & \multirow{5}{*}{ 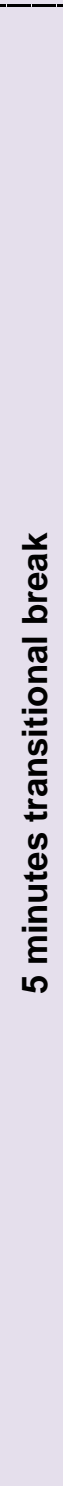 } & $10.35-11.00$ \\
\hline 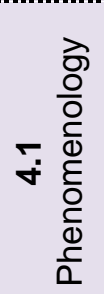 & $\begin{array}{l}4.1 .1 \\
\text { Abstract number } 260 \\
\text { Rebuilding and restructuring the world } \\
\text { following hyper acute assessment and } \\
\text { treatment for an acute stroke. } \\
\text { Dr Joanne Brooke, Kent Community } \\
\text { Health NHS Trust, United Kingdom }\end{array}$ & & $\begin{array}{l}4.1 .2 \\
\text { Abstract number } 204 \\
\text { Why undertake pilot work in a qualitative PhD } \\
\text { study? Lessons learnt to promote success } \\
\text { Jane Wray, University of Bradford, United } \\
\text { Kingdom }\end{array}$ \\
\hline 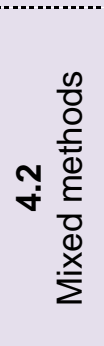 & $\begin{array}{l}4.2 .1 \\
\text { Abstract number } 169 \\
\text { The use of nominal group technique in } \\
\text { a 'bottom up' approach to survey item } \\
\text { development: involving service users } \\
\text { and clinicians. } \\
\text { Dr Kay Currie, Glasgow Caledonian } \\
\text { University, United Kingdom }\end{array}$ & & $\begin{array}{l}4.2 .2 \\
\text { Abstract number } 46 \\
\text { What } \mathbf{Q} \text { can do for you- using } \mathbf{Q} \text { methodology } \\
\text { in healthcare } \\
\text { Elaine Baxter, Nottingham Univeristy Hospitals } \\
\text { NHS Trust, United Kingdom }\end{array}$ \\
\hline 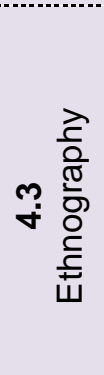 & $\begin{array}{l}4.3 .1 \\
\text { Abstract number } 285 \\
\text { Administering anticipatory } \\
\text { medications in end of life care: A } \\
\text { qualitative study of nursing practice in } \\
\text { the community and in nursing homes } \\
\text { in England } \\
\text { Professor Jane Seymour,University of } \\
\text { Nottingham, United Kingdom }\end{array}$ & & $\begin{array}{l}4.3 .2 \\
\text { Abstract number } 45 \\
\text { "Breaking down the walls" - exploring } \\
\text { psychological defences in health } \\
\text { professionals } \\
\text { Laura Middleton-Green, University of Bradford, } \\
\text { United Kingdom }\end{array}$ \\
\hline 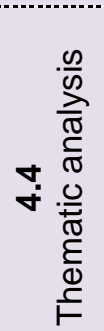 & $\begin{array}{l}4.4 .1 \\
\text { Abstract number } 71 \\
\text { Late diagnosis of cleft palate: The role } \\
\text { of specialist cleft nurses as 'rescuers' } \\
\text { Dr Stephanie Tierney, Royal College of } \\
\text { Nursing Research Institute, United } \\
\text { Kingdom }\end{array}$ & & $\begin{array}{l}4.4 .2 \\
\text { Abstract number } 148 \\
\text { Identifying the support needs of residential } \\
\text { support workers working with older people } \\
\text { with intellectual disabilities who develop } \\
\text { health problems. } \\
\text { Professor Ruth Northway, University of South } \\
\text { Wales, United Kingdom }\end{array}$ \\
\hline
\end{tabular}




\begin{tabular}{|c|c|c|}
\hline 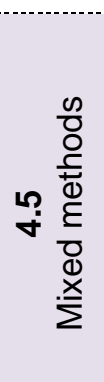 & $\begin{array}{l}4.5 .1 \\
\text { Abstract number } 30 \\
\text { The daily relationships between } \\
\text { staffing, workload and safety } \\
\text { perceptions within hospital nursing: } \\
\text { Does personality play a role? } \\
\text { Dr Gemma Louch, Bradford Teaching } \\
\text { Hospitals NHS Foundation Trust, United } \\
\text { Kingdom }\end{array}$ & $\begin{array}{l}\text { Abstract number } 212 \\
\text { The PAONCIL method for nurse staffing and } \\
\text { for assessing non-patient factors that affect } \\
\text { nurses' total workload } \\
\text { Professor Lisbeth Fagerström, Buskerud and } \\
\text { Vestfold University College, United Kingdom }\end{array}$ \\
\hline 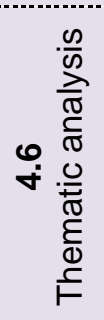 & $\begin{array}{l}4.6 .1 \\
\text { Abstract number } 28 \\
\text { To stay or not to stay'- children's } \\
\text { nurses experiences of parental } \\
\text { presence during resuscitation } \\
\text { Laura Crowley, Royal Belfast Hospital for } \\
\text { Sick Children, United Kingdom }\end{array}$ & $\begin{array}{l}4.6 .2 \\
\text { Abstract number } 94 \\
\text { Difficulties experienced by nurses and allied } \\
\text { healthcare professionals when } \\
\text { communicating bad, sad or significant news. } \\
\text { Clare Warnock, Weston Park Hospital, United } \\
\text { Kingdom }\end{array}$ \\
\hline 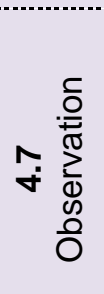 & $\begin{array}{l}4.7 .1 \\
\text { Abstract number } 322 \\
\text { A pragmatic randomised controlled } \\
\text { trial of sugar in the management of } \\
\text { sloughy necrotic exudating wounds } \\
\text { Moses Murandu, University of } \\
\text { Wolverhampton, United Kingdom }\end{array}$ & \\
\hline
\end{tabular}

$11.00-11.30 \quad$ Refreshments, exhibition viewing \& poster judging/viewing

\section{$11.30-12.55 \quad$ Concurrent session 5}

\begin{tabular}{|c|c|c|c|c|c|}
\hline \multicolumn{6}{|c|}{ Concurrent session 5} \\
\hline & $11.30-11.55$ & & $12.00-12.25$ & & $12.30-12.55$ \\
\hline $\begin{array}{r}\frac{\partial}{0} \\
\text { in } \\
\text { in } \\
\frac{0}{0} \\
\frac{0}{0} \\
\frac{0}{0}\end{array}$ & $\begin{array}{l}5.1 .1 \\
\text { Abstract number } 271 \\
\text { Exploring the lived } \\
\text { experience of dementia: } \\
\text { Methodological challenges } \\
\text { of interviewing people } \\
\text { living with dementia of } \\
\text { black ethnicity } \\
\text { Perfect Tiritega Mawaka, } \\
\text { Barking and Dagenham, } \\
\text { Havering and Redbridge } \\
\text { Clinical Commissioning } \\
\text { Group, United Kingdom }\end{array}$ & & $\begin{array}{l}5.1 .2 \\
\text { Abstract number } 52 \\
\text { Open fracture of the lower } \\
\text { limb: patients' experience } \\
\text { whilst in acute care } \\
\text { Dr Liz Tutton, University of } \\
\text { Warwick, United Kingdom }\end{array}$ & 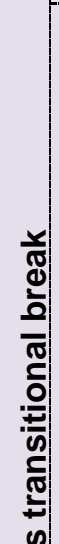 & $\begin{array}{l}5.1 .3 \\
\text { Abstract number } 178 \\
\text { A lived Experience of sickle } \\
\text { cell patients during and } \\
\text { after their crisis } \\
\text { Mudhar Mohammed Al } \\
\text { Adawi, Rustaq Hospital, } \\
\text { Oman }\end{array}$ \\
\hline 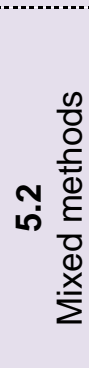 & $\begin{array}{l}5.2 .1 \\
\text { Abstract number } 88 \\
\text { What worked? A Realist } \\
\text { Evaluation of } \\
\text { Intermediaries in Infection } \\
\text { Prevention and Control } \\
\text { Dr Lynne Williams, Bangor } \\
\text { University, United Kingdom }\end{array}$ & : & $\begin{array}{l}5.2 .2 \\
\text { Abstract number } 182 \\
\text { Normalisation Process } \\
\text { Theory: a useful method for } \\
\text { informing the evaluation of } \\
\text { complex interventions? } \\
\text { Susan Jones, Teesside } \\
\text { University, United Kingdom }\end{array}$ & 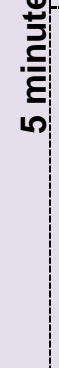 & $\begin{array}{l}5.2 .3 \\
\text { Abstract number } 181 \\
\text { Theoretical Domain } \\
\text { Framework: is this a useful } \\
\text { tool for interrogating } \\
\text { behaviour change in } \\
\text { complex interventions? } \\
\text { Susan Jones, Teesside } \\
\text { University, United Kingdom }\end{array}$ \\
\hline
\end{tabular}




\begin{tabular}{|c|c|c|c|}
\hline 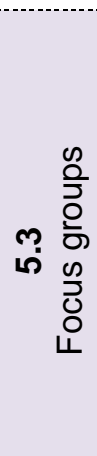 & $\begin{array}{l}5.3 .1 \\
\text { Abstract number } 18 \\
\text { Flexible working hours and } \\
\text { career planning for nurses } \\
\text { over } 50 \text { : an exploratory } \\
\text { study } \\
\text { Dr Jill Clendon, New Zealand } \\
\text { Nurses Organisation, New } \\
\text { Zealand }\end{array}$ & $\begin{array}{l}5.3 .2 \\
\text { Abstract number } 72 \\
\text { Student nurses' } \\
\text { explanations of nursing } \\
\text { failures: a focus group } \\
\text { study } \\
\text { Professor Michael Traynor, } \\
\text { Middlesex University, United } \\
\text { Kingdom }\end{array}$ & $\begin{array}{l}5.3 .3 \\
\text { Abstract number } 97 \\
\text { A vision for clinical } \\
\text { leadership: "Appreciating" } \\
\text { the development needs of } \\
\text { registered nurses working } \\
\text { in the Aged and Residential } \\
\text { Care sector in New } \\
\text { Zealand. } \\
\text { Shelly Crick, Whitireia, New } \\
\text { Zealand }\end{array}$ \\
\hline 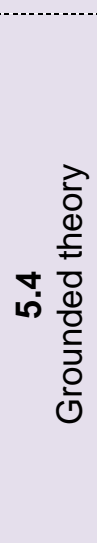 & $\begin{array}{l}5.4 .1 \\
\text { Abstract number } 86 \\
\text { Situational Analysis: Its } \\
\text { use in reflexivity, reviewing } \\
\text { the literature and preparing } \\
\text { for data collection. } \\
\text { Sarah Morey, Northumbria } \\
\text { University, United Kingdom }\end{array}$ & $\begin{array}{l}5.4 .2 \\
\text { Abstract number } 27 \\
\text { A qualitative study using } \\
\text { grounded theory analysis to } \\
\text { explore the impact of group } \\
\text { work as a method of service } \\
\text { delivery by Community } \\
\text { Matrons to support those } \\
\text { living with multiple long- } \\
\text { term conditions } \\
\text { Dr Abigail Barkham, Southern } \\
\text { Health NHS Foundation Trust, } \\
\text { United Kingdom }\end{array}$ & $\begin{array}{l}5.4 .3 \\
\text { Abstract number } 229 \\
\text { Human factors affect the } \\
\text { response of doctors and } \\
\text { nurses to a high MEWS } \\
\text { score. } \\
\text { Jane Greaves, Northumbria } \\
\text { University, United Kingdom }\end{array}$ \\
\hline 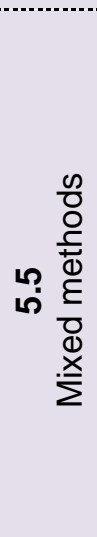 & $\begin{array}{l}5.5 .1 \\
\text { Abstract number } 278 \\
\text { Women's experiences of } \\
\text { trained volunteer doula } \\
\text { support during pregnancy, } \\
\text { labour and the postpartum } \\
\text { Professor Helen Spiby, } \\
\text { University of Nottingham, } \\
\text { United Kingdom }\end{array}$ & $\begin{array}{l}5.5 .2 \\
\text { Abstract number } 272 \\
\text { "I have no wish to be at the } \\
\text { tender mercies of a } \\
\text { homophobic carer/service": } \\
\text { exploring end of life } \\
\text { experiences and care needs } \\
\text { in the lives of older lesbian, } \\
\text { gay, bisexual or trans } \\
\text { (LGBT) people. } \\
\text { Professor Jane Seymour, } \\
\text { University of Nottingham, } \\
\text { United Kingdom }\end{array}$ & $\begin{array}{l}5.5 .3 \\
\text { Abstract number } 73 \\
\text { Meeting the physical and } \\
\text { psychological health needs } \\
\text { of young people involved } \\
\text { in sexual exploitation - an } \\
\text { empirical study } \\
\text { Dr Gabrielle Tracy } \\
\text { McClelland, University of } \\
\text { Bradfiord, United Kingdom }\end{array}$ \\
\hline 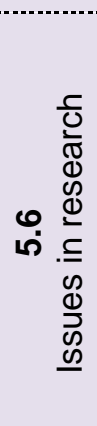 & $\begin{array}{l}5.6 .1 \\
\text { Abstract number } 270 \\
\text { Working participatively } \\
\text { with Gypsies and } \\
\text { Travellers: insights from a } \\
\text { study exploring } \\
\text { immunisation in the } \\
\text { Travelling community } \\
\text { Dr Louise Condon, Swansea } \\
\text { University, United Kingdom }\end{array}$ & $\begin{array}{l}5.6 .2 \\
\text { Abstract number } 222 \\
\text { Collaborative Working: } \\
\text { Overcoming the challenges } \\
\text { of meeting the Dementia } \\
\text { Challenge } \\
\text { Karen Palmer, Lancashire } \\
\text { Care NHS Foundation Trust, } \\
\text { United Kingdom }\end{array}$ & $\begin{array}{l}5.6 .3 \\
\text { Abstract number } 231 \\
\text { Service user preferences } \\
\text { for involvement in care } \\
\text { planning in mental health } \\
\text { services } \\
\text { Andrew Grundy, Queens } \\
\text { Medical Centre, United } \\
\text { Kingdom }\end{array}$ \\
\hline 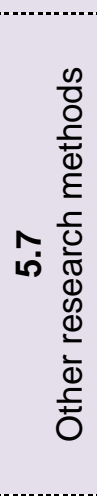 & $\begin{array}{l}5.7 .1 \\
\text { Abstract number } 308 \\
\text { Survey of current pin site } \\
\text { practices } \\
\text { Jennie Walker, Nottingham } \\
\text { University Hospital, United } \\
\text { Kingdom }\end{array}$ & $\begin{array}{l}5.7 .2 \\
\text { Abstract number } 323 \\
\text { The experience of moral } \\
\text { distress in undergraduate } \\
\text { nursing students } \\
\text { Annamaria Bagnasco, } \\
\text { University of Genoa, Italy }\end{array}$ & $\begin{array}{l}5.7 .3 \\
\text { Abstract number } 335 \\
\text { What does "good" look } \\
\text { like? How qualitative } \\
\text { methods revealed the } \\
\text { effects of meaningful } \\
\text { activity training (mat) for } \\
\text { older people with dementia } \\
\text { Deborah Mazhindu, } \\
\text { Buckinghamshire New } \\
\text { University \& Imperial College } \\
\text { Healthcare, United Kingdom }\end{array}$ \\
\hline
\end{tabular}




\section{$14.00-14.55 \quad$ Concurrent session 6}

\begin{tabular}{|c|c|c|c|}
\hline \multicolumn{4}{|c|}{ Concurrent session 6} \\
\hline & $14.00-14.25$ & \multirow{6}{*}{ 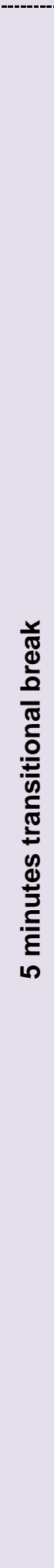 } & $14.30-14.55$ \\
\hline 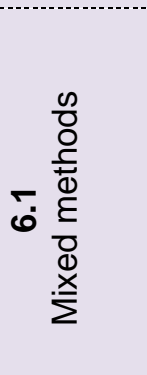 & $\begin{array}{l}6.1 .1 \\
\text { Abstract number } 5 \\
\text { Female gender doubles pre- } \\
\text { hospital delay times for patients } \\
\text { experiencing ST segment } \\
\text { elevation myocardial infarction in } \\
\text { Saudi Arabia } \\
\text { Dr Hassan Alshahrani, King Saud } \\
\text { Medical City, Saudi Arabia }\end{array}$ & & $\begin{array}{l}6.1 .2 \\
\text { Abstract number } 176 \\
\text { Testing and evaluating a person centred care } \\
\text { complex intervention in relation to dignity and } \\
\text { palliative care in the acute hospital setting } \\
\text { Professor Bridget Johnston, The University of } \\
\text { Nottingham, United Kingdom }\end{array}$ \\
\hline ขู & $\begin{array}{l}6.2 .1 \\
\text { Abstract number } 120 \\
\text { Siblings talking the visual: } \\
\text { Narrative accounts of children's } \\
\text { everyday lives. Living with a } \\
\text { brother or sister with cystic } \\
\text { fibrosis. } \\
\text { Amie Hodges, Cardiff University, } \\
\text { United Kingdom }\end{array}$ & & $\begin{array}{l}6.2 .2 \\
\text { Abstract number } 269 \\
\text { A Voice for the child. Blue's story of managing } \\
\text { her illness at home. } \\
\text { Dr Marie Bodycombe-James, Swansea University, } \\
\text { United Kingdom }\end{array}$ \\
\hline 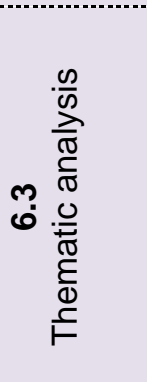 & $\begin{array}{l}6.3 .1 \\
\text { Abstract number } 287 \\
\text { Lung cancer diagnosed following } \\
\text { an emergency admission: } \\
\text { Exploring patients' and carers' } \\
\text { perspectives on delay in seeking } \\
\text { help } \\
\text { Professor Jane Seymour, University } \\
\text { of Nottingham, United Kingdom }\end{array}$ & & $\begin{array}{l}6.3 .2 \\
\text { Abstract number } 17 \\
\text { An exploratory study to identify factors that help } \\
\text { or hinder ward nurses from performing vital } \\
\text { observations and escalating clinical concerns: } \\
\text { An interview study applying a theoretical } \\
\text { domains framework. } \\
\text { Andrea Blay, Chelsea \& Westminster NHS } \\
\text { Foundation Trust, United Kingdom }\end{array}$ \\
\hline 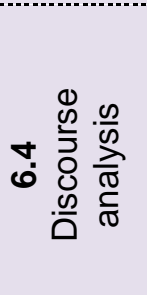 & $\begin{array}{l}6.4 .1 \\
\text { Abstract number } 196 \\
\text { The Good Old Days? } \\
\text { Constructions of nurse education } \\
\text { in British national newspapers } \\
\text { Dr Karen Gillett, King's College } \\
\text { London, United Kingdom }\end{array}$ & & $\begin{array}{l}6.4 .2 \\
\text { Abstract number } 154 \\
\text { Assertive community treatment case managers' } \\
\text { moral decision-making } \\
\text { Birgitte Lerbæk, Aalborg University Hospital, } \\
\text { Denmark }\end{array}$ \\
\hline 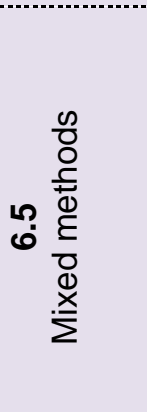 & $\begin{array}{l}6.5 .1 \\
\text { Abstract number } 43 \\
\text { Understanding nursing leadership } \\
\text { in commissioning roles: learning } \\
\text { from senior nurses' experiences of } \\
\text { clinical commissioning groups in } \\
\text { the UK } \\
\text { Professor Helen Therese Allan, } \\
\text { Middlesex University, United } \\
\text { Kingdom }\end{array}$ & & $\begin{array}{l}6.5 .2 \\
\text { Abstract number } 144 \\
\text { Ward culture and pressure ulcer prevention: } \\
\text { barriers and enablers to care? } \\
\text { Eleanore Dring, Nottingham University Hospitals } \\
\text { Trust, United Kingdom }\end{array}$ \\
\hline
\end{tabular}




\begin{tabular}{|c|c|c|}
\hline 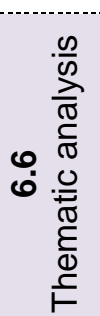 & $\begin{array}{l}6.6 .1 \\
\text { Abstract number } 188 \\
\text { What leaders describe as affecting } \\
\text { the adoption of healthcare } \\
\text { improvements } \\
\text { Michael Sykes, Tees, Esk \& Wear } \\
\text { Valleys NHS FT, United Kingdom }\end{array}$ & $\begin{array}{l}6.6 .2 \\
\text { Abstract number } 80 \\
\text { The experience of gay male student nurses: } \\
\text { Negotiating private lives and professional } \\
\text { boundaries. } \\
\text { Dr Dave Clarke, Cardiff University, United Kingdom }\end{array}$ \\
\hline 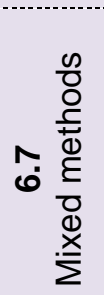 & 6.7 .1 & $\begin{array}{l}6.7 .2 \\
\text { Abstract number } 60 \\
\text { Facilitators and barriers to integrating a nurse } \\
\text { practitioner into the team: Co-workers' } \\
\text { perceptions } \\
\text { Dr Esther Sangster-Gormley, University of Victoria, } \\
\text { Canada }\end{array}$ \\
\hline
\end{tabular}

$14.55-15.25 \quad$ Refreshments, exhibition viewing \& poster judging/viewing

$15.25-16.25 \quad$ Symposia (3 or 4 paper)

\begin{tabular}{|c|c|c|c|}
\hline \multicolumn{4}{|l|}{ Symposium 1: } \\
\hline $\begin{array}{l}\text { Big Data: opportunities } \\
\text { and challenges for } \\
\text { nursing (91) } \\
\text { Dr lain Atherton, } \\
\text { University of Stirling, } \\
\text { United Kingdom }\end{array}$ & $\begin{array}{l}\text { Paper 1: } \\
\text { Tracking the impact of } \\
\text { emotional intelligence and } \\
\text { previous caring } \\
\text { experience on student } \\
\text { nurse progression: A } \\
\text { longitudinal study } \\
\\
\text { Rosie Stenhouse, } \\
\text { Scotland; Austyn } \\
\text { Snowden, Scotland. }\end{array}$ & $\begin{array}{l}\text { Paper 2: } \\
\text { Know thyself: utilising } \\
\text { routinely collected data to } \\
\text { gain insight into the social } \\
\text { determinants of nurses' } \\
\text { health } \\
\text { Richard Kyle, Scotland; } \\
\text { Rosie Neall, Scotland; } \\
\text { Chris Dibben, Scotland; } \\
\text { lain Atherton, Scotland. }\end{array}$ & $\begin{array}{l}\text { Paper 3: } \\
\text { To measure is to know } \\
\text { Roger Watson, United } \\
\text { Kingdom. }\end{array}$ \\
\hline \multicolumn{4}{|l|}{ Symposium 2: } \\
\hline $\begin{array}{l}\text { Using Consensus } \\
\text { methods to build } \\
\text { research capacity within } \\
\text { Community Nursing in } \\
\text { Wales (248) } \\
\text { Dr Carolyn Wallace, } \\
\text { University South Wales, } \\
\text { United Kingdom }\end{array}$ & $\begin{array}{l}\text { Paper 1: } \\
\text { Building and coordinating } \\
\text { the Community Nursing } \\
\text { Research strategy for } \\
\text { Wales using Nominal } \\
\text { Group Technique } \\
\text { Carolyn Wallace, Wales; } \\
\text { Joyce Kenkre, Wales; } \\
\text { Robyn Davies, Wales; } \\
\text { Sue Bale, Wales; Sue } \\
\text { Thomas, Wales. }\end{array}$ & $\begin{array}{l}\text { Paper 2: } \\
\text { Using Concept Mapping in } \\
\text { a mixed-method study to } \\
\text { develop a patient } \\
\text { assessment instrument for } \\
\text { district nurses to identify } \\
\text { community-based patient } \\
\text { complexity } \\
\text { Sue Thomas, Wales; } \\
\text { Carolyn Wallace, Wales, } \\
\text { Paul Jarvis, Wales, Ruth } \\
\text { Davis, Wales. }\end{array}$ & $\begin{array}{l}\text { Paper 3: } \\
\text { Using Consensus } \\
\text { Methods to evaluate an } \\
\text { Erasmus Intensive } \\
\text { Learning Project } \\
\text { David Pontin, Wales; } \\
\text { Carolyn Wallace, Wales; } \\
\text { Liisa Koskinen \& Irma } \\
\text { Mikkonen, Finland; Klara } \\
\text { Dokova \& Sonya } \\
\text { Toncheva, Bulgaria; Irene } \\
\text { Hartigan, Aileen Burton \& } \\
\text { Angela Flynn, Eire. }\end{array}$ \\
\hline
\end{tabular}




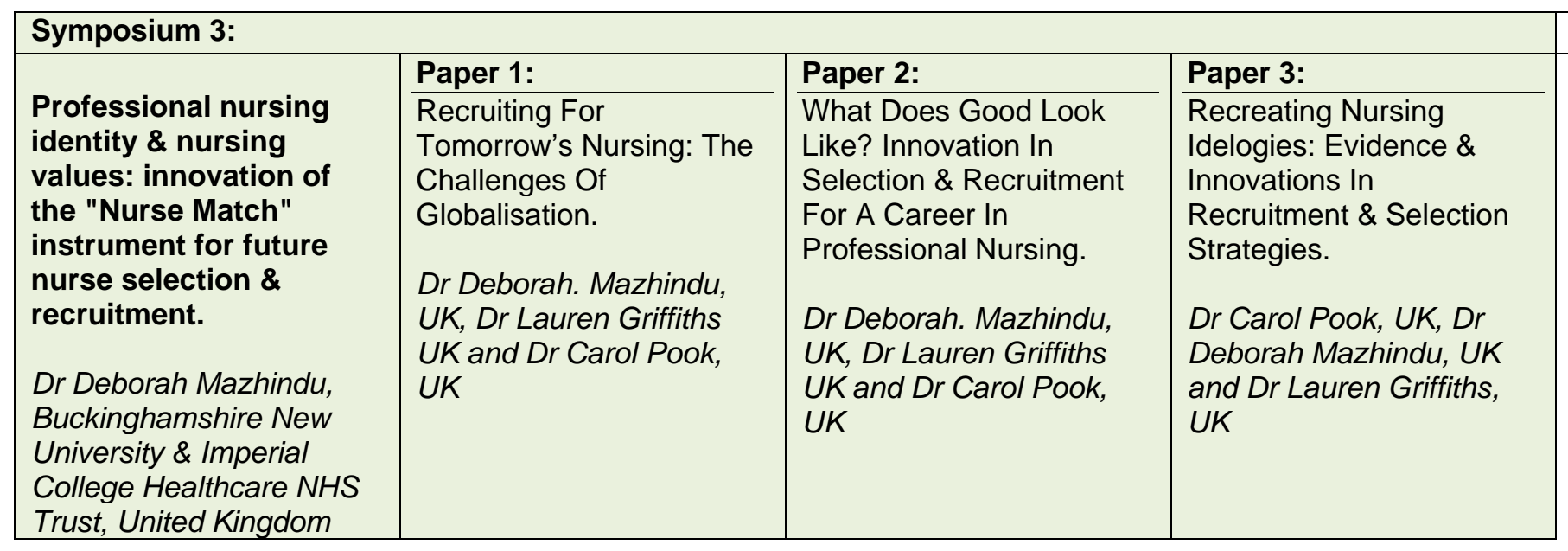

5 minute transitional break

\section{$16.30-17.30 \quad$ Fringe/ Networking events}

\begin{tabular}{|c|c|c|c|}
\hline $\begin{array}{l}\text { Developing nurses' } \\
\text { professional practice } \\
\text { and knowledge: an } \\
\text { exploration of funding } \\
\text { and scholarship } \\
\text { opportunities } \\
\text { Dr Sharon Hamilton, } \\
\text { Teeside University and } \\
\text { Dr Theresa Shaw, } \\
\text { Foundation of Nursing } \\
\text { Studies }\end{array}$ & $\begin{array}{l}\text { Developing partnerships } \\
\text { to share experience and } \\
\text { expertise } \\
\text { Nicola McHugh, Global } \\
\text { Research Nurses' Network } \\
\text { Violet Nour, Al-Ahliyya } \\
\text { University (Jordan) } \\
\text { Patience Ngina Ndonye, } \\
\text { Kilifi (Kenya) } \\
\text { Gillian Ray-Barruel, Griffith } \\
\text { University (Australia) }\end{array}$ & $\begin{array}{l}\text { I am a member of the } \\
\text { RCN, why should I } \\
\text { promote membership to } \\
\text { the Research Society? } \\
\text { Michael Traynor, Ruth } \\
\text { Northway, Ruth Harris, } \\
\text { Bridie Kent, Julie McGarry, } \\
\text { Danny Kelly and Rachel } \\
\text { Taylor, The RCN } \\
\text { Research Society }\end{array}$ & $\begin{array}{l}\text { Becoming an effective } \\
\text { reviewer } \\
\text { Carol Haigh, Debra } \\
\text { Jackson, Graeme Smith, } \\
\text { Leslie Gelling and Susan } \\
\text { Barnason, Manchester } \\
\text { Metropolitan University }\end{array}$ \\
\hline
\end{tabular}


$08.30-09.00 \quad$ Registration, refreshments, exhibition viewing \& poster judging/viewing

$09.00-09.10 \quad$ Chairs' welcome and introduction to conference day three

$09.10-09.50 \quad$ Reform of Care or Care of Reform? Revitalising, Being alongside and Nursing Practices

Professor Joanna Latimer, School of Social Sciences,

Cardiff University

$09.50-10.45 \quad$ Concurrent session 7

\begin{tabular}{|c|c|c|c|}
\hline \multicolumn{4}{|c|}{ Concurrent session 7} \\
\hline & $09.50-10.15$ & \multirow{6}{*}{ 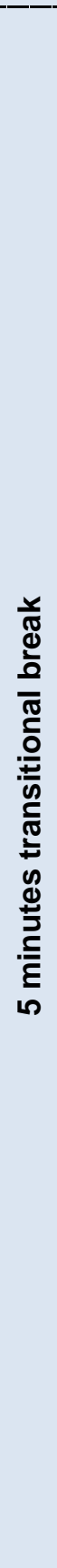 } & $10.20-10.45$ \\
\hline 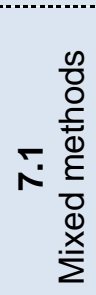 & $\begin{array}{l}7.1 .1 \\
\text { Abstract number } 255 \\
\text { Nursing interventions for the care of } \\
\text { young rural people with early mental } \\
\text { health problems } \\
\text { Dr Rhonda Wilson, University of New } \\
\text { England, Australia }\end{array}$ & & $\begin{array}{l}7.1 .2 \\
\text { Abstract number } 58 \\
\text { Domestic violence and abuse (DVA) in acute } \\
\text { care settings: findings from a qualitative study } \\
\text { exploring health care responses } \\
\text { Dr Julie McGarry, University of Nottingham, United } \\
\text { Kingdom }\end{array}$ \\
\hline 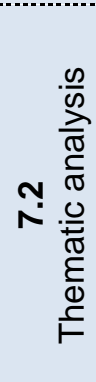 & $\begin{array}{l}7.2 .1 \\
\text { Abstract number } 124 \\
\text { Adhering to anti-depressant } \\
\text { medication: A medication-taking } \\
\text { career } \\
\text { Dr Niels Buus, University of Southern } \\
\text { Denmark, Denmark }\end{array}$ & & $\begin{array}{l}7.2 .2 \\
\text { Abstract number } 228 \\
\text { "We're killing them with medicine": Community } \\
\text { Mental Health Nurse perspectives towards } \\
\text { cardiovascular risk in adults with severe and } \\
\text { enduring mental illness- A Directed Content } \\
\text { Analysis } \\
\text { James Lambie, Edinburgh Access Practice, United } \\
\text { Kingdom }\end{array}$ \\
\hline & $\begin{array}{l}7.3 .1 \\
\text { Abstract number } 111 \\
\text { Understanding the needs of women } \\
\text { with adenomyosis through social } \\
\text { media. } \\
\text { Dr Camille Cronin, University of Essex, } \\
\text { United Kingdom }\end{array}$ & & $\begin{array}{l}7.3 .2 \\
\text { Abstract number } 75 \\
\text { Resilient leadership in a time of crisis: an } \\
\text { interview study of Directors of Nursing in the } \\
\text { wake of Francis. } \\
\text { Professor Daniel Kelly, Cardiff University, United } \\
\text { Kingdom }\end{array}$ \\
\hline 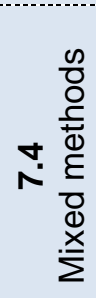 & $\begin{array}{l}7.4 .1 \\
\text { Abstract number } 310 \\
\text { The contribution of advanced nursing } \\
\text { practice to HIV care: findings from } \\
\text { stage } 1 \text { of a national study } \\
\text { Hilary Piercy, Sheffield Hallam } \\
\text { University, United Kingdom }\end{array}$ & & $\begin{array}{l}7.4 .2 \\
\text { Abstract number } 175 \\
\text { Using participatory research to develop a } \\
\text { palliative care intervention: reflections on the } \\
\text { method } \\
\text { Dr Beth Hardy, The University of Nottingham, } \\
\text { United Kingdom }\end{array}$ \\
\hline 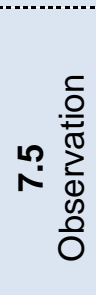 & $\begin{array}{l}7.5 .1 \\
\text { Abstract number } 259 \\
\text { Evaluating interruptions to } \\
\text { medication administration in } \\
\text { paediatric critical care } \\
\text { Rachel Bower, Nottingham University } \\
\text { Hospital Trust, United Kingdom }\end{array}$ & & $\begin{array}{l}7.5 .2 \\
\text { Abstract number } 118 \\
\text { Factors associated with 'care left undone' on } \\
\text { nursing shifts in Sweden } \\
\text { Jane Ball, University of Southampton, United } \\
\text { Kingdom }\end{array}$ \\
\hline
\end{tabular}




\begin{tabular}{|c|c|c|}
\hline 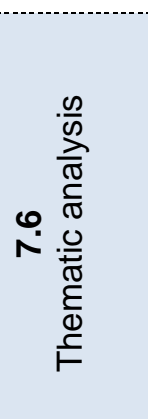 & $\begin{array}{l}7.6 .1 \\
\text { Abstract number } 81 \\
\text { The DECIDES Study: Living with } \\
\text { Crohn's Disease: expectations, } \\
\text { experlences and decision-making in } \\
\text { relation to best conventional and } \\
\text { autologous stem cell treatment } \\
\text { Dr Joanne Cooper, Notttingham } \\
\text { University Hosptials NHS Trust, United } \\
\text { Kingdom }\end{array}$ & \\
\hline 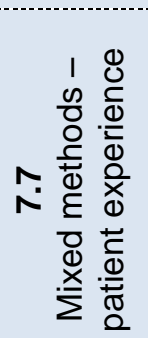 & $\begin{array}{l}7.7 .1 \\
\text { Abstract number } 289 \\
\text { A case study of the advanced nurse } \\
\text { practitioner consultation in primary } \\
\text { care: communication processes and } \\
\text { social interactions } \\
\text { Julian Barratt, University of } \\
\text { Wolverhampton, United Kingdom }\end{array}$ & $\begin{array}{l}7.7 .2 \\
\text { Abstract number } 125 \\
\text { Patients have an opportunity to tell it as it is: a } \\
\text { mixed methods analysis of patient incident } \\
\text { reports in three NHS Trusts in the UK } \\
\text { Sally Moore, Bradford Institute for Health Research } \\
\text { United Kingdom }\end{array}$ \\
\hline
\end{tabular}

10.45 - $11.15 \quad$ Refreshments, exhibition viewing \& poster judging/viewing

11.15 - $12.40 \quad$ Concurrent session 8

\begin{tabular}{|c|c|c|c|c|c|}
\hline \multicolumn{6}{|c|}{ Concurrent session 8} \\
\hline & $11.15-11.40$ & \multirow{3}{*}{ 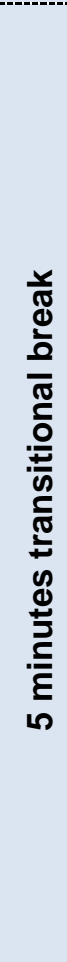 } & $11.45-12.10$ & \multirow{3}{*}{ 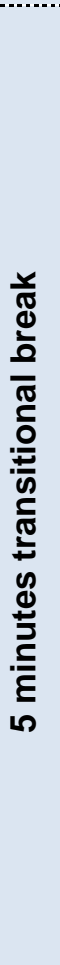 } & $12.15-12.40$ \\
\hline $\bar{\infty}$ & $\begin{array}{l}8.1 .1 \\
\text { Abstract number } 113 \\
\text { International } \\
\text { perspectives on social } \\
\text { media guidance for } \\
\text { nurses: a content } \\
\text { analysis } \\
\text { Gemma Ryan, University } \\
\text { of Derby, United } \\
\text { Kingdom }\end{array}$ & & $\begin{array}{l}8.1 .2 \\
\text { Abstract number } 325 \\
\text { Impact Evaluation of the } \\
\text { RCN's First Steps online } \\
\text { learning resource for } \\
\text { HCAs } \\
\text { Tommy Cheng, Royal } \\
\text { College of Nursing, United } \\
\text { Kingdom }\end{array}$ & & $\begin{array}{l}8.1 .3 \\
\text { Abstract number } 256 \\
\text { MetaMood: The } \\
\text { development and clinical } \\
\text { pilot trial of a mental health } \\
\text { e-health intervention using } \\
\text { an android smart device } \\
\text { app. } \\
\text { Dr Rhonda Wilson, University } \\
\text { of New England, Australia }\end{array}$ \\
\hline 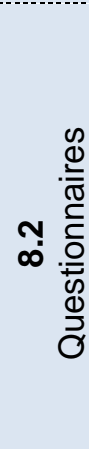 & $\begin{array}{l}8.2 .1 \\
\text { Abstract number } 109 \\
\text { Developing healthier } \\
\text { student nurses } \\
\text { Professor Jane Wills, } \\
\text { London South Bank } \\
\text { University, United } \\
\text { Kingdom }\end{array}$ & & $\begin{array}{l}8.2 .2 \\
\text { Abstract number } 235 \\
\text { Towards burnout } \\
\text { prevention in nursing } \\
\text { Nina Geuens, Karel de } \\
\text { Grote University College, } \\
\text { Belgium }\end{array}$ & & $\begin{array}{l}8.2 .3 \\
\text { Abstract number } 15 \\
\text { Alcohol-related liver disease } \\
\text { patients' beliefs about their } \\
\text { illness and factors that } \\
\text { influence their self- } \\
\text { management- a patient } \\
\text { survey. } \\
\text { Dr Jonathan Presky, King's } \\
\text { College London, United } \\
\text { Kingdom }\end{array}$ \\
\hline
\end{tabular}




\begin{tabular}{|c|c|c|c|}
\hline 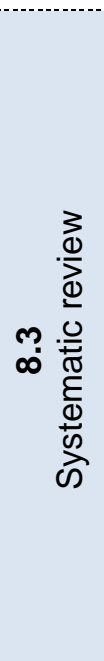 & $\begin{array}{l}8.3 .1 \\
\text { Abstract number } 107 \\
\text { Unpacking the } \\
\text { methodological and } \\
\text { practice challenges of } \\
\text { realist synthesis: } \\
\text { experiences from a } \\
\text { realist review of } \\
\text { workforce development } \\
\text { for the assistant care } \\
\text { workforce caring for } \\
\text { older people } \\
\text { Professor Jo Rycroft- } \\
\text { Malone, Bangor } \\
\text { University, United } \\
\text { Kingdom }\end{array}$ & $\begin{array}{l}8.3 .2 \\
\text { Abstract number } 106 \\
\text { Improving training and } \\
\text { development for the } \\
\text { assistant care workforce } \\
\text { in older people's care: } \\
\text { findings from a realist } \\
\text { synthesis } \\
\text { Dr Lynne Williams, Bangor } \\
\text { University, United Kingdom }\end{array}$ & $\begin{array}{l}8.3 .3 \\
\text { Abstract number } 16 \\
\text { Psychological well-being in } \\
\text { carers of someone with } \\
\text { cancer: a systematic review } \\
\text { Jenny Young, University of the } \\
\text { West of Scotland, United } \\
\text { Kingdom }\end{array}$ \\
\hline 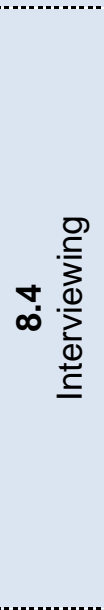 & $\begin{array}{l}8.4 .1 \\
\text { Abstract number } 313 \\
\text { To disclose or not to } \\
\text { disclose. An } \\
\text { exploration of the } \\
\text { multi-disciplinary } \\
\text { team's role in advising } \\
\text { patients about } \\
\text { disclosure when } \\
\text { diagnosed with genital } \\
\text { herpes simplex virus } \\
\text { (HSV). } \\
\text { Pauline Caulfield, } \\
\text { Sandyford Initiative, } \\
\text { United Kingdom }\end{array}$ & $\begin{array}{l}8.4 .2 \\
\text { Abstract number } 293 \\
\text { The impact of a National } \\
\text { Junior Leadership } \\
\text { Academy on leadership } \\
\text { identity in UK student } \\
\text { nurses. } \\
\text { Stacy Johnson, University } \\
\text { of Nottingham, United } \\
\text { Kingdom }\end{array}$ & $\begin{array}{l}8.4 .3 \\
\text { Abstract number } 303 \\
\text { Breaking the 'silence': initial } \\
\text { findings from a qualitative } \\
\text { study using a new research } \\
\text { framework to explore the } \\
\text { recovery experiences of } \\
\text { middle aged adults with an } \\
\text { isolated hip fracture. } \\
\text { Gillian Janes, School of } \\
\text { Health and Social Care, } \\
\text { Teesside University, United } \\
\text { Kingdom }\end{array}$ \\
\hline 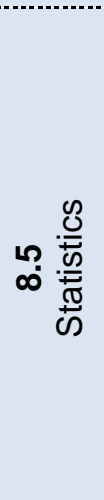 & $\begin{array}{l}8.5 .1 \\
\text { Abstract number } 67 \\
\text { "Yeah, it's very hard for } \\
\text { the women from } \\
\text { Africa": Understanding } \\
\text { the health issues of } \\
\text { circumcised migrant } \\
\text { women in Australia. } \\
\text { Professor Lesley Wilkes, } \\
\text { Centre for Nursing } \\
\text { Research and Practice } \\
\text { Development, Australia }\end{array}$ & $\begin{array}{l}8.5 .2 \\
\text { Abstract number } 51 \\
\text { Factors related to low } \\
\text { compliance to Iron } \\
\text { supplements among } \\
\text { pregnant women in } \\
\text { Middle Eastern } \\
\text { University hospital } \\
\text { Dr. Vidya Seshan, Sultan } \\
\text { Qaboos University, Oman }\end{array}$ & $\begin{array}{l}8.5 .3 \\
\text { Abstract number } 135 \\
\text { Quality of life and self-care } \\
\text { ability of patients with } \\
\text { permeant pacemaker } \\
\text { implantation } \\
\text { Professor Shu-Fen Su, } \\
\text { Hungkuang University, Taiwan }\end{array}$ \\
\hline 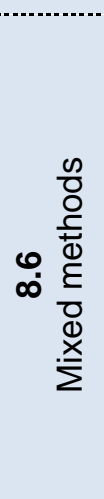 & $\begin{array}{l}8.6 .1 \\
\text { Abstract number } 217 \\
\text { A mixed-methods case } \\
\text { study to examine ward } \\
\text { leadership in the } \\
\text { organisational context } \\
\text { of an acute NHS Trust } \\
\text { Natasha Phillips, } \\
\text { University College } \\
\text { Hospitals London NHS } \\
\text { Foundation Trust, United } \\
\text { Kingdom }\end{array}$ & $\begin{array}{l}8.6 .2 \\
\text { Abstract number } 32 \\
\text { Nurse leaders in an NHS } \\
\text { Foundation Trust : A } \\
\text { mixed methods study of } \\
\text { empowerment } \\
\text { (qualitative phases) } \\
\text { Dr Caroline Spencer, Guys } \\
\text { and St Thomas NHS } \\
\text { Foundation Trust, United } \\
\text { Kingdom }\end{array}$ & $\begin{array}{l}8.6 .3 \\
\text { Abstract number } 329 \\
\text { Supporting the support } \\
\text { staff: evidence to support a } \\
\text { 'senses framework' } \\
\text { approach to care in older } \\
\text { people's wards } \\
\text { Sophie Sarre, Kings College } \\
\text { London, United Kingdom }\end{array}$ \\
\hline
\end{tabular}




$\left[\begin{array}{|c|l|l|}\hline & \begin{array}{l}8.7 .1 \\ \text { Abstract number } 338 \\ \text { An exploratory, } \\ \text { descriptive, qualitative } \\ \text { study to increase } \\ \text { understanding around } \\ \text { shared decision } \\ \text { making in relation to } \\ \text { health visitor practice } \\ \text { Ruth Astbury, NHS } \\ \text { Greater Glasgow and } \\ \text { Clyde, United Kingdom }\end{array}\end{array}\right]$

$12.40-13.40 \quad$ Lunch, exhibition viewing, poster judging/viewing

Presenters will be at their posters from $13.10-13.40$

$13.40-15.10 \quad$ Symposia (4 or 5 paper)

\begin{tabular}{|c|c|c|c|c|c|}
\hline \multicolumn{6}{|l|}{ Symposium 4: } \\
\hline $\begin{array}{l}\text { Developing } \\
\text { nursing research } \\
\text { capacity and } \\
\text { capability in } \\
\text { clinical settings: } \\
\text { overcoming } \\
\text { barriers and } \\
\text { developing } \\
\text { opportunity (92) } \\
\text { Professor Lesley } \\
\text { Baillie, London } \\
\text { South Bank } \\
\text { University and } \\
\text { University College } \\
\text { London Hospitals, } \\
\text { United Kingdom }\end{array}$ & $\begin{array}{l}\text { Paper 1: } \\
\text { The Cooke } \\
\text { Framework for } \\
\text { research } \\
\text { capacity building } \\
\text { Jo Cooke*, UK }\end{array}$ & $\begin{array}{l}\text { Paper 2: } \\
\text { Clinical academic } \\
\text { roles and their } \\
\text { contribution to } \\
\text { increasing research } \\
\text { capability and } \\
\text { capacity of clinical } \\
\text { nurses } \\
\text { Professor Debbie } \\
\text { Carrick-Sen* UK } \\
\text { and Professor } \\
\text { Christine Norton, } \\
\text { UK. }{ }^{*}\end{array}$ & $\begin{array}{l}\text { Paper 3: } \\
\text { Establishing a } \\
\text { collaborative } \\
\text { network of clinical } \\
\text { academic chairs: } \\
\text { the Florence } \\
\text { Nightingale } \\
\text { Foundation model } \\
\text { for increasing } \\
\text { research } \\
\text { capability and } \\
\text { capacity of clinical } \\
\text { nurses } \\
\text { Professor Lesley } \\
\text { Baillie, UK. }\end{array}$ & $\begin{array}{l}\text { Paper 4: } \\
\text { Applying a } \\
\text { facilitative model } \\
\text { for increasing } \\
\text { research } \\
\text { capability and } \\
\text { capacity of } \\
\text { nurses and } \\
\text { midwives } \\
\text { Lesley Baillie*, } \\
\text { UK, Kay } \\
\text { Mitchell*, UK, } \\
\text { Natasha } \\
\text { Phillips }{ }^{*}, U K .\end{array}$ & $\begin{array}{l}\text { Paper 5: } \\
\text { Adapting the } \\
\text { Cooke } \\
\text { Framework for } \\
\text { Research } \\
\text { Capacity } \\
\text { Building } \\
\\
\text { Christi Deaton* } \\
\text { UK and Angela } \\
\text { Tod }^{*} \text { UK. }\end{array}$ \\
\hline \multicolumn{6}{|l|}{ Symposium 5: } \\
\hline $\begin{array}{l}\text { EURECA: } \\
\text { Exploring, } \\
\text { Understanding and } \\
\text { Reducing } \\
\text { Emergency Cancer } \\
\text { Admissions: a } \\
\text { critical case study } \\
\text { (282) } \\
\text { Dr Cara Bailey, } \\
\text { University of } \\
\text { Birmingham, United } \\
\text { Kingdom }\end{array}$ & $\begin{array}{l}\text { Paper 1: } \\
\text { A systematic } \\
\text { review of the } \\
\text { reasons for } \\
\text { emergency } \\
\text { admissions } \\
\text { amongst } \\
\text { patients with } \\
\text { cancer } \\
\text { ‘Daniel Munday, } \\
\text { Nepal; Eleni } \\
\text { Karasouli, UK;; } \\
\text { Cara Bailey, UK; } \\
\text { Alistair } \\
\text { Hewison,UK; } \\
\text { Roberta Lovick; } \\
\text { UK, Sophie } \\
\text { Staniszewska, } \\
\text { S, UK; Frances } \\
\text { Griffiths, UK. }\end{array}$ & $\begin{array}{l}\text { Paper 2: } \\
\text { 'Holding on or } \\
\text { letting go' - } \\
\text { complex decision } \\
\text { making before } \\
\text { emergency } \\
\text { admissions by } \\
\text { patients with lung } \\
\text { cancer and } \\
\text { advanced COPD } \\
\text { Daniel Munday, } \\
\text { Nepal; Cara Bailey, } \\
\text { UK; Eleni } \\
\text { Karasouli, UK; } \\
\text { ‘Alistair } \\
\text { Hewison,UK; } \\
\text { Roberta Lovick; } \\
\text { UK, Sophie } \\
\text { Staniszewska, S, } \\
\text { UK; Frances } \\
\text { Griffiths, UK; Daniel } \\
\text { Munday, Nepal. }\end{array}$ & $\begin{array}{l}\text { Paper 3: } \\
\text { “It seemed like a } \\
\text { long wait!" - } \\
\text { Experiences of } \\
\text { hospital care } \\
\text { following } \\
\text { emergency } \\
\text { admissions at the } \\
\text { end of life } \\
\text { *Cara Bailey, UK; } \\
\text { Eleni Karasouli, } \\
\text { UK; Alistair } \\
\text { Hewison,UK; } \\
\text { Roberta Lovick; } \\
\text { UK, Sophie } \\
\text { Staniszewska, S, } \\
\text { UK; Frances } \\
\text { Griffiths, UK; } \\
\text { Daniel Munday, } \\
\text { Nepal. }\end{array}$ & $\begin{array}{l}\text { Paper 4: } \\
\text { At the "crisis } \\
\text { point" - The role } \\
\text { of community } \\
\text { healthcare } \\
\text { professionals in } \\
\text { reducing } \\
\text { emergency } \\
\text { admissions of } \\
\text { people with } \\
\text { advanced } \\
\text { COPD and lung } \\
\text { cancer: a } \\
\text { secondary } \\
\text { analysis } \\
\text { *Gemma } \\
\text { Chance, UK; } \\
\text { Cara Bailey, UK; } \\
\text { Alistair } \\
\text { Hewison,UK; } \\
\text { Daniel Munday, } \\
\text { Nepal. }\end{array}$ & $\begin{array}{l}\text { Paper 5: } \\
\text { The 'glue' to } \\
\text { insightful } \\
\text { understanding in } \\
\text { research - } \\
\text { Patient and } \\
\text { public } \\
\text { involvement in } \\
\text { the EURECA } \\
\text { study } \\
\text { ‘Sophie } \\
\text { Staniszewska } \\
\text { UK; S., Li Gunn, } \\
\text { UK; Daniel } \\
\text { Munday,Nepal; } \\
\text { Roberta Lovick, } \\
\text { UK; Eleni } \\
\text { Karasouli,UK; } \\
\text { Cara Bailey, UK. }\end{array}$ \\
\hline
\end{tabular}




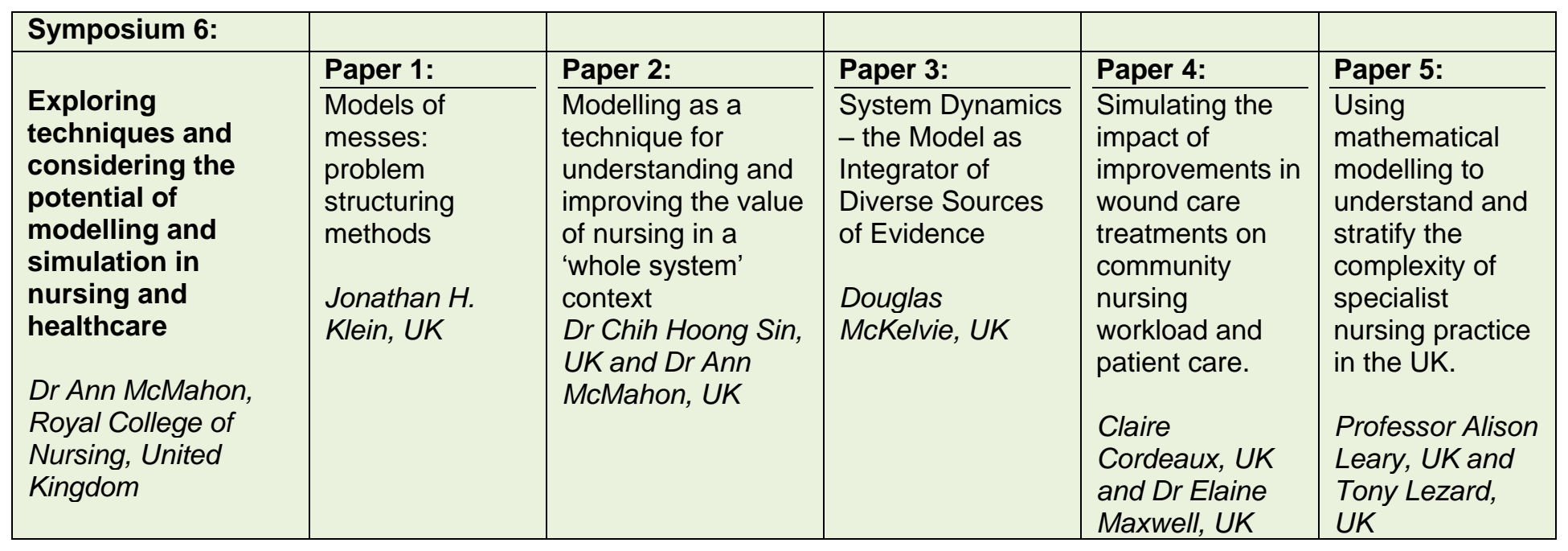

$15.10-15.30 \quad$ Refreshments and exhibition viewing

$15.30-15.35 \quad$ Chairs' welcome back

15.35 - $16.15 \quad$ Research Excellence Framework: from a 2014 Curate's Egg to a 2020 Golden Egg!

Professor Hugh McKenna, Pro-Vice-Chancellor (Research and Innovation), Ulster University

16.15- 16.25 RCN Conference 2016

16.25- $16.30 \quad$ Conference summary and close 


\section{Posters}

\section{Monday 20 April 2015}

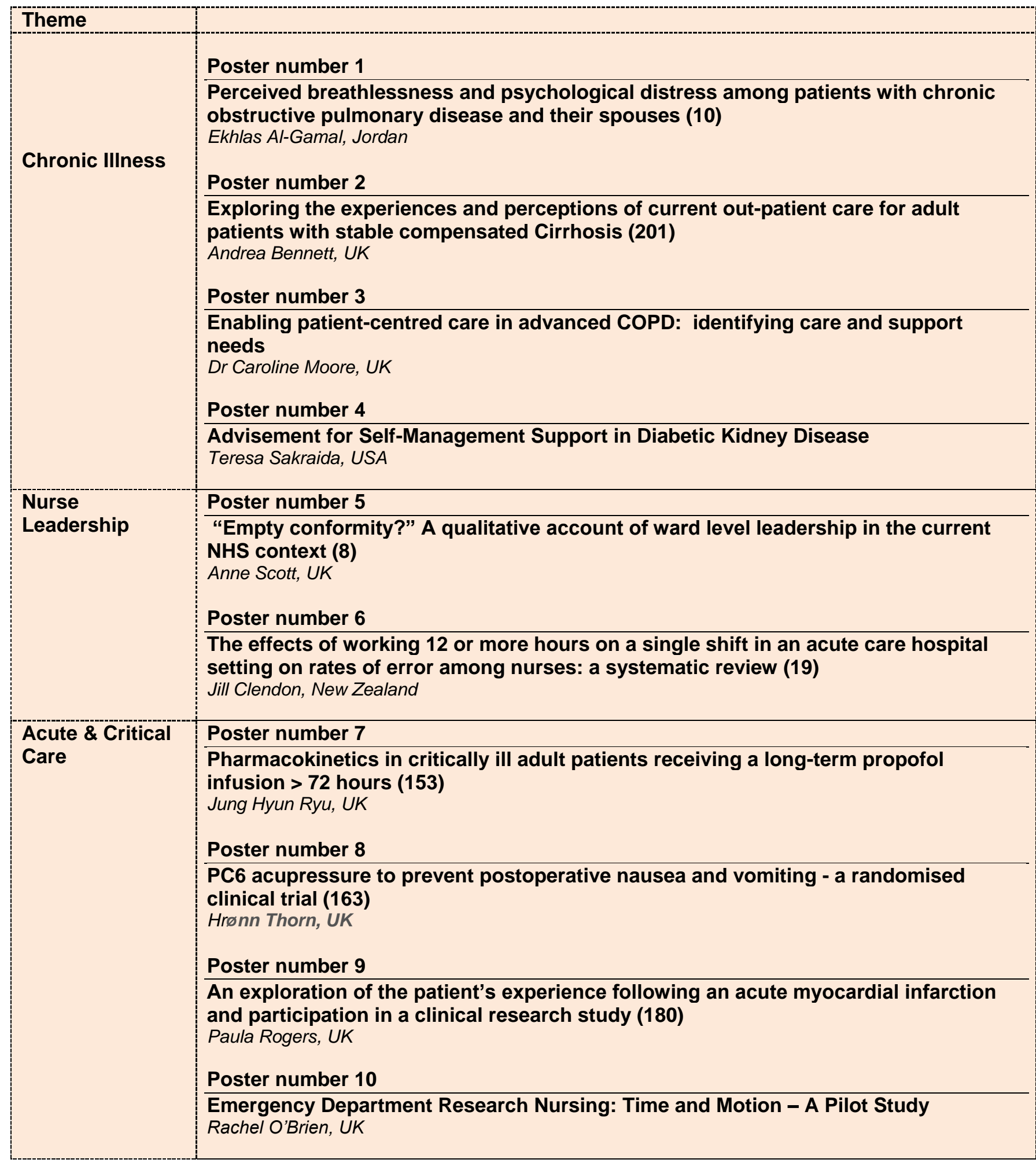




\begin{tabular}{|l|l|}
\hline Workforce & $\begin{array}{l}\text { Poster number 11 } \\
\text { Level of Hepatitis B virus protection of first year medicine and nursing students in } \\
\text { Mbarara University (36) } \\
\text { Samson Wakibi, Uganda } \\
\text { Poster number 12 }\end{array}$ \\
\hline $\begin{array}{l}\text { Body weight perception and dietary control methods among Egyptian university } \\
\text { students (146) } \\
\text { Doaa Yacout, Egypt }\end{array}$ \\
\hline $\begin{array}{l}\text { Women's health } \\
\text { and midwifery }\end{array}$ & $\begin{array}{l}\text { Poster number 13 } \\
\text { Breast or cervical cancer screening? Preventive behavior of Hong Kong community- } \\
\text { dwelling Chinese Women } \\
\text { Besty Pui Ying Cheng, Hong Kong }\end{array}$ \\
\hline
\end{tabular}




\section{Tuesday 21 April 2015}

\begin{tabular}{|c|c|}
\hline Theme & Tuesday 21 April \\
\hline Child health & $\begin{array}{l}\text { Poster number } 14 \\
\text { The impact of a school-based asthma health education programme on quality of } \\
\text { life, knowledge and attitudes of Saudi children with asthma (241) } \\
\text { Nashi Alreshidi, KSA } \\
\text { Poster number } 15 \\
\text { Making and revising end-of-life care decisions: parents' experiences (104) } \\
\text { Emma Popejoy, UK } \\
\text { Poster number } 16 \\
\text { A timeline of personal grooming behaviours over the lifespan (127) } \\
\text { Jan Woodhouse, UK } \\
\text { Poster number } 17 \\
\text { Comparison of the expressed experiences of survivors of childhood } \\
\text { medulloblastoma with measures of health and quality of life, and with issues } \\
\text { identified during consultations: improving rapid and proactive response to } \\
\text { problems (232) } \\
\text { Tony Long, UK } \\
\text { Poster number } 19 \\
\begin{array}{l}\text { The challenges and reality of patient and public involvement (PPI) with teenagers } \\
\text { and young adults } \\
\text { Anita Solanki, UK }\end{array}\end{array}$ \\
\hline $\begin{array}{l}\text { Workforce } \\
\text { development }\end{array}$ & $\begin{array}{l}\text { Poster number } 20 \\
\text { The obstacle course: an exploration of the obstacles to BME health care support } \\
\text { staff accessing training opportunities (145) } \\
\text { Sarah Rutherford, UK } \\
\text { Poster number } 21 \\
\text { Cognitive Behavioural Therapy: initial orientation and training for undergraduate } \\
\text { mental health nursing students in the UK (219) } \\
\text { Stephen Bates, UK } \\
\text { Poster number } 22 \\
\text { The implementation of evidence based practice among mental health nurses (240) } \\
\text { Evridiki Patelarou, UK } \\
\text { Poster number } 23 \\
\text { What is meant by quality nursing care for people with dementia in a day hospital } \\
\text { setting? (195) } \\
\text { Darren Prince, UK }\end{array}$ \\
\hline Older people & $\begin{array}{l}\text { Poster number } 24 \\
\text { Oral health care in nursing homes and nursing education (138) } \\
\text { Kurt Arild Krokmyrdal, Norway } \\
\text { Poster number } 25 \\
\text { Moderately increased day time activities for elderly women do not change sleep } \\
\text { quality in nursing homes (170) } \\
\text { Keiko Tanida, Japan } \\
\text { Poster number } 26 \\
\text { Sorted study: enabling older people to take part in a clinical trial (187) } \\
\text { Lorna Ingoe, UK } \\
\text { Poster number } 27 \\
\text { Ward discharge planning program on medication management for older patients } \\
\text { admitted to acute medical unit } \\
\text { Hiu Kiu Leung, China }\end{array}$ \\
\hline
\end{tabular}




\begin{tabular}{|l|l|}
\hline Research issues & $\begin{array}{l}\text { Poster number } 28 \\
\text { Development of a Hospice Research Strategy through organisational consensus } \\
(39) \\
\text { Elizabeth Reed, UK } \\
\text { Poster number } 29 \\
\text { Increasing research capacity and capability: the role of the research assistant } \\
\text { (102) } \\
\text { Rhian Bull, UK }\end{array}$ \\
\hline
\end{tabular}


Wednesday 22 April 2015

\begin{tabular}{|c|c|}
\hline Theme & \\
\hline End of life care & $\begin{array}{l}\text { Poster number } 30 \\
\text { Where are the voices? Advance care planning and Black Asian and minority ethnic } \\
\text { communities in the UK: a critical review of research (93) } \\
\text { Zoebia Islam, UK }\end{array}$ \\
\hline Health promotion & $\begin{array}{l}\text { Poster number } 31 \\
\text { Secondhand smoke exposure in a smoker's family: nursing instructor role (198) } \\
\text { Vimolpun Nitipong, Thailand } \\
\text { Poster number } 32 \\
\text { Intimate Partner Violence: Exploring the Perspective of Practitioners Dealing with IPV } \\
\text { Victims from Muslim Community (294) } \\
\text { Parveen Ali, UK }\end{array}$ \\
\hline $\begin{array}{l}\text { Cardiovascular } \\
\text { disease and stroke }\end{array}$ & $\begin{array}{l}\text { Poster number } 33 \\
\text { Use and access of primary healthcare services in rural areas in Southern Greece } \\
\text { (133) } \\
\text { Zacharenia Androulaki, Greece } \\
\text { Poster number } 34 \\
\text { Arrythmias perceptions, quality of life, and associated factors of cardiovascular } \\
\text { patients before pacemaker implantation (99) } \\
\text { Shu-Fen Su, Taiwan }\end{array}$ \\
\hline Workforce issues & $\begin{array}{l}\text { Poster number } 35 \\
\text { The use of 'pop-up education' to raise nurses' awareness of research being } \\
\text { conducted in the emergency department (247) } \\
\text { Harriet Couper, UK }\end{array}$ \\
\hline Acute \& Critical Care & $\begin{array}{l}\text { Poster number } 36 \\
\text { Exploration of the process in applying sedation guidelines to critical care patients } \\
\text { among ICU nurses (174) } \\
\text { Chiung-Fen Shih, Taiwan } \\
\text { Poster number } 37 \\
\text { Findings from a global peripheral intravenous catheter prevalence study } \\
\text { Gillian Ray-Barruel, Australia } \\
\text { Poster number } 38 \\
\text { Facing life's realities after the stroke } \\
\text { Rochelle Colas, Philippines } \\
\text { Poster number } 39 \\
\text { Effectiveness of nurse-led person-centered behavioral risk modification on } \\
\text { secondary prevention of coronary heart disease: A systematic review } \\
\text { Chung Yang Chiang, Hong Kong } \\
\text { Poster number } 40 \\
\text { Documentary analysis of } 100 \text { palliative day-care records provides complex baseline } \\
\text { data } \\
\text { George Kernohan, UK } \\
\text { Poster number } 41 \\
\text { Assessment of safe prescribing in final year undergraduate medical students } \\
\text { Selina Jarvis, UK } \\
\text { Poster number } 42 \\
\text { Saudi Students' Perceptions of the Nursing Profession } \\
\text { Hammad Alroqi, UK }\end{array}$ \\
\hline
\end{tabular}


